Ethos (Jurnal Penelitian dan Pengabdian Masyarakat): 221-232

\title{
Studi Penggunaan Gambut Lokal Untuk Pengolahan Air Limbah Domestik SECARA BATCH
}

\author{
Munawar \\ Jurusan Teknik Kimia Politeknik Negeri Lhokseumawe, Jl. B. Aceh-Medan Km 280, Buketrata, \\ Lhokseumawe 24301, Telp. (0645)42670 \\ E-mail: munawwar.r1@gmail.com
}

\begin{abstract}
Abstrak. Gambut merupakan salah satu adsorben alternatif yang layak dipilih untuk pengolahan air limbah. Sekalipun penelitian tentang gambut sudah banyak dilakukan, gambut Indonesia termasuk jenis gambut yang belum banyak dipelajari penggunaannya untuk kegiatan pengendalian pencemaran. Penelitian ini bertujuan mempelajari kinerja gambut lokal Aceh untuk tujuan pengolahan air limbah domestik. Percobaan dilakukan secara batch pada temperatur $26 \pm 3{ }^{\circ} \mathrm{C}$, dengan memvariasikan metode preparasi gambut (AP-1, AP-2, AP-3, AP-4, AP-5) dan dosis adsorben $(10,20,40 \mathrm{~g} / \mathrm{L})$. Sedangkan variabel tetap adalah volume limbah $(50 \mathrm{~mL})$, dan kecepatan pengadukan (125 rpm). Hasil penelitian menunjukkan bahwa preparasi awal dengan kapur dan besi terbukti efektif untuk meningkatkan kinerja gambut sebagai adsorben. Gambut segar dengan perlakuan kapur dan besi mampu mereduksi beberapa parameter utama air limbah domestik dengan efisiensi optimum 28,1\% untuk penyisihan COD, 88,6\% untuk penyisihan deterjen, dan $91 \%$ untuk penyisihan kekeruhan, serta 94,79\% untuk penyisihan E. Coli.
\end{abstract}

Kata kunci : air limbah domestik, COD, deterjen, gambut, kekeruhan

\section{Pendahuluan}

Indonesia merupakan salah satu negara berkembang dengan tingkat pertumbuhan penduduk yang cukup tinggi di dunia. Data BPS tahun 2000 menunjukkan bahwa pertumbuhan penduduk Indonesia mencapai $1,49 \%$ per tahun, dan diperkirakan tidak berbeda signifikan pada tahun 2010. Dengan jumlah penduduk lebih dari 230 juta jiwa, Indonesia menghadapi berbagai permasalahan yang cukup kompleks, mulai dari tingkat kemiskinan yang masih tinggi, sulitnya lapangan pekerjaan, mahalnya biaya pendidikan, hingga masalah-masalah khas negara berkembang seperti urbanisasi dan pencemaran lingkungan.

Sebagai negara berkembang, Indonesia hanya memiliki anggaran terbatas dan regulasi yang lemah dalam pengelolaan dan pengedalian pencemaran lingkungan. Dalam pengelolaan air buangan misalnya, penggunaan proses pengolahan berbiaya tinggi menjadi tidak reliable dan tidak ekonomis. Akibatnya, dengan alasan efisiensi biaya, penanganan air buangan hanya dilakukan seadanya tanpa memperhatikan efisiensi dan keberlanjutannya. Saking buruknya penanganan limbah di negeri ini (hanya mampu melayani kurang dari $1 \%$ penduduk), sebagian sungai di kota besar telah 
berubah wujud menjadi selokan atau tangki septik terbuka untuk berbagai jenis limbah yang terus-menerus dibuang.

Air limbah domestik merupakan jenis limbah yang paling sering mencemari air tanah dan air permukaan. Dari sisi kuantitas, limbah domestik merupakan jenis limbah yang paling banyak dibuang ke lingkungan. Penanganan limbah domestik yang tidak reliable akan meningkatkan potensi pencemaran tanah, air permukaan dan air tanah. Karena itu, pengembangan sistem pengolahan yang simpel dan berbiaya rendah dipandang sangat layak untuk dilakukan.

Pengolahan air limbah domestik umumnya dilakukan dengan proses biologis yaitu dengan metode lumpur aktif. Pengembangan metode pengolahan alternatif dipandang cukup urgen mengingat makin meningkatnya kuantitas limbah yang dibuang ke lingkungan, sementara instalasi demikian masih langka di Indonesia (Notodarmojo, 2005). Pilihan yang cukup menarik adalah menggunakan proses pengolahan berbasis material berbiaya rendah dan memiliki performansi tinggi. Penelitian ini merekomendasikan penerapan proses adsorpsi berbasis gambut sebagai sorben berbiaya rendah (low cost adsorbent). Menurut Ho dkk (1995) selama beberapa dekade terakhir, potensi gambut sebagai material untuk pengontrolan pencemaran air telah diakui secara luas. Sepanjang periode ini, sistem-sistem berbasis gambut telah banyak direkomendasikan sebagai solusi yang potensial untuk berbagai permasalahan dalam skala luas.

Gambut merupakan material yang tersedia dalam jumlah melimpah di Indonesia. Namun pemanfaatan sumber daya alam tersebut tergolong masih sangat terbatas. Penelitian-penelitian tentang penggunaan gambut Indonesia untuk pengolahan air limbah dapat dikatakan masih sangat minim. Dengan demikian, mengingat ketersediaan material yang melimpah, biaya penanganan yang relatif murah, serta performansi yang cukup baik sebagai adsorben, penggunaan gambut sebagai bioadsorben diharapkan dapat memberikan solusi alternatif untuk pengolahan air limbah domestik.

Penelitian ini bertujuan mempelajari kinerja gambut lokal Aceh untuk tujuan pengolahan air limbah domestik. Ruang lingkup penelitian meliputi: 1) studi pengaruh perlakuan awal adsorben, serta; 2) studi pengaruh dosis adsorben terhadap penyisihan COD dan deterjen dari limbah domestik, serta; 3) studi unjuk kerja sistem berbasis gambut untuk pengolahan air limbah domestik.

\section{Metode Penelitian}

\subsection{Adsorben}

Gambut yang digunakan dalam penelitian ini adalah gambut lokal yang diambil Desa Nisam Kecamatan Geureudong Pase Kabupaten Aceh Utara. Untuk mengetahui sifat-sifat bahan, dilakukan pengujian karakteristik fisika-kimia, meliputi analisis $\mathrm{pH}$, kadar air, bahan organik, kandungan mineral, kapasitas tukar kation (KTK), densitas 
bulk dan porositas total. Sebelum digunakan sebagai adsorben, gambut dipreparasi dengan empat prosedur berikut:

1) Gambut dikeringkan pada temperatur $105{ }^{\circ} \mathrm{C}$ selama 2-8 jam (Ho dan McKay, 2004) hingga beratnya konstan, dilanjutkan dengan penyesuaian ukuran partikel gambut menggunakan standar test sieve, sehingga didapatkan ukuran partikel antara 10/70 mesh (disebut AP-1).

2) Gambut kering setelah perlakuan (1) dicampur dengan $\mathrm{CaCO}_{3}$ (sebanyak $15 \%$ dari volume gambut basah), diaduk homogenkan, lalu ditambahkan $\mathrm{FeCl}_{3}$ sejumlah $10 \%$ dari massa gambut kering (disebut AP-2).

3) Gambut kering setelah perlakuan (1) direndam dalam larutan $\mathrm{CaCO}_{3} 1 \mathrm{M}(15 \%$ volume) selama 30 menit, kemudian disaring untuk mendapatkan fraksi solid dan dikeringkan selama 2 jam pada temperatur $105{ }^{\circ} \mathrm{C}$. Gambur selanjutnya direndam dalam larutan $\mathrm{FeCl}_{3}$ selama 30 menit, lalu disaring dan dikeringkan selama 2-8 jam di dalam oven pada temperatur $105{ }^{\circ} \mathrm{C}$ hingga diperoleh berat konstan (disebut AP$3)$.

4) Gambut kering setelah perlakuan (1) direndam dalam larutan $\mathrm{CaCO}_{3} 1 \mathrm{M}(85 \%$ volume) selama 30 menit, kemudian disaring untuk mendapatkan fraksi solid dan dikeringkan selama 2 jam pada temperatur $105{ }^{\circ} \mathrm{C}$. Gambur selanjutnya direndam dalam larutan $\mathrm{FeCl}_{3}$ selama 30 menit, lalu disaring dan dikeringkan selama 2-8 jam di dalam oven pada temperatur $105{ }^{\circ} \mathrm{C}$ hingga diperoleh berat konstan (disebut AP$3)$.

5) Gambut basah direndam dalam larutan $\mathrm{CaCO}_{3} 1 \mathrm{M}$ selama 30 menit, kemudian disaring untuk mendapatkan fraksi solid dan dikeringkan selama 2 jam pada temperatur $105{ }^{\circ} \mathrm{C}$. Gambut selanjutnya direndam dalam larutan $\mathrm{FeCl}_{3}$ selama 30 menit, lalu disaring dan dikeringkan selama 2-8 jam pada temperatur $105{ }^{\circ} \mathrm{C}$ hingga diperoleh berat konstan (disebut AP-4).

\subsection{Air limbah domestik}

Limbah domestik yang digunakan dalam penelitian ini diambil dari beberapa titik pada saluran air utama Waduk Air Pusong Kota Lhokseumawe yang merupakan waduk buangan akhir limbah domestik kota Lhokseumawe.

\subsection{Percobaan batch}

Percobaan sorpsi dilakukan di dalam sejumlah labu erlenmeyer volume $125 \mathrm{~mL}$, pada temperatur ruang $\left(26 \pm 3{ }^{\circ} \mathrm{C}\right)$. Gambut yang telah dipreparasi dimasukkan ke dalam erlenmeyer dalam beberapa variasi dosis, lalu kontakkan dengan $50 \mathrm{~mL}$ air domestik, dan diaduk pada rotary shaker selama 3 jam (Munawar, 2007). Setelah selesai, supernatan diambil secara secara filtrasi, dan di analisis konsentrasi residual COD dan deterjen dalam air limbah. Metode uji parameter penelitian ditunjukkan pada Tabel 1. 
Tabel 1. Metode uji parameter penelitian

\begin{tabular}{lc}
\hline \multicolumn{1}{c}{ Paramater uji } & Metode \\
\hline COD & Standar method, \\
& 1998 \\
Deterjen & Standar method, \\
& 1998 \\
Turbidity & Standar method, \\
& 1998 \\
\hline
\end{tabular}

\subsection{Studi unjuk kerja sistem}

Percobaan ini merupakan fundamen untuk menetapkan variabel operasi peralatan adsorpsi yang akan dikembangkan. Data-data sekunder para peneliti terdahulu tidak dapat langsung digunakan, mengingat studi-studi tersebut dilakukan dengan gambut yang berbeda dengan yang digunakan dalam penelitian ini. Tujuan yang ingin dicapai dari percobaan ini adalah mendapatkan kondisi operasi optimum bioadsorber untuk penyisihan parameter air limbah domestik, sebagai dasar untuk aplikasi sistem dalam proses kontinyu. Pada percobaan batch, air limbah domestik dialirkan ke dalam adsorber dengan debit antara 10-30 L/menit. Secara berkala, dilakukan sampling dan diperiksa kualitas air limbah dengan metode yang disebutkan dalam Tabel 2.

Tabel 2. Metode karakterisasi air limbah

\begin{tabular}{lcc}
\hline Parameter & Metode & Referensi \\
\hline COD & $\begin{array}{l}\text { Standar } \\
\text { Method }\end{array}$ & APHA, 1998 \\
Turbidity & $\begin{array}{l}\text { Standar } \\
\text { Method }\end{array}$ & APHA, 1998 \\
& $\begin{array}{l}\text { Standar } \\
\text { Deterjen }\end{array}$ & APHA, 1998 \\
& $\begin{array}{l}\text { Method } \\
\text { Standar }\end{array}$ & APHA, 1998 \\
\hline
\end{tabular}

\subsection{Prototipe Bioadsorber}

Bioadsorber yang digunakan dalam penelitian adalah adsorber dengan kapasitas 30 L/menit yang dioperasikan sebagai Fixed Bed Column (FBC) Adsorber dan Fluidized (Pulse) Bed Column (PBC) Adsorber. Rencana instalasi peralatan dan sistem perpipaan ditunjukkan pada Gambar 1. 


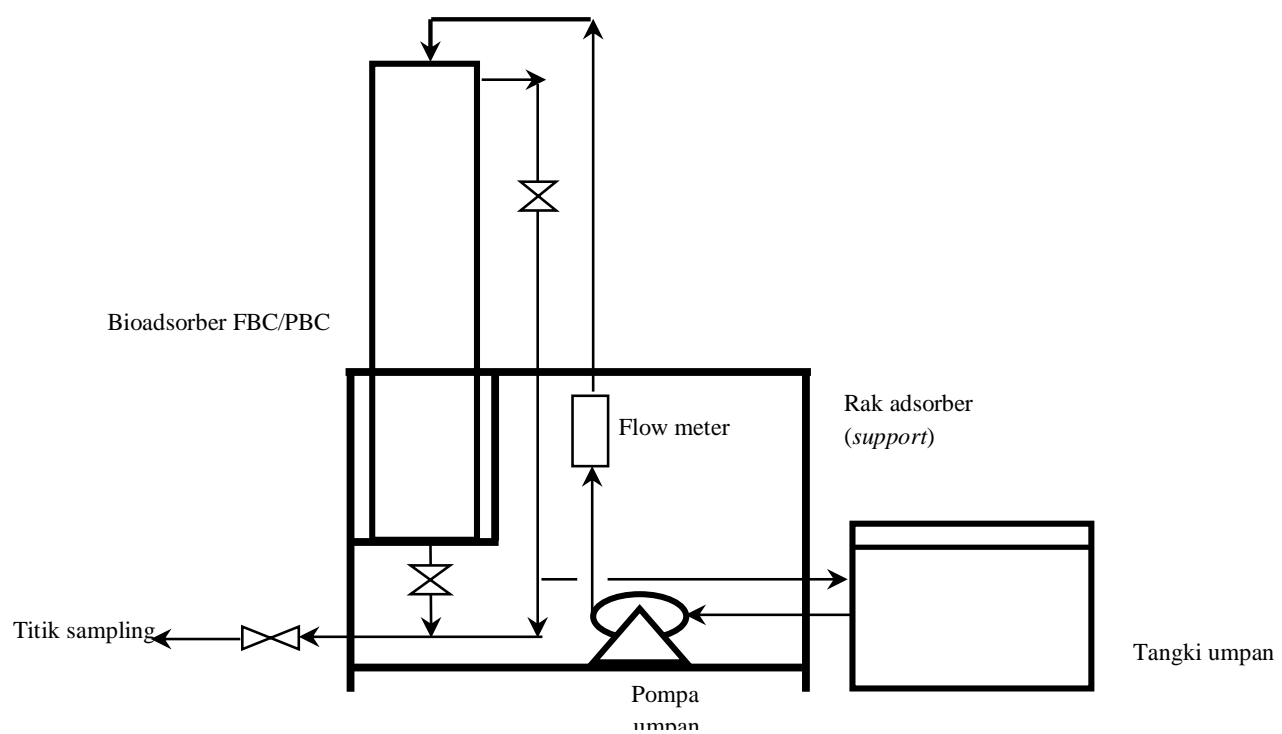

Gambar 1. Prototipe Bioadsorber

\subsection{Analisis Data Penelitian}

Data-data pengujian peralatan akan dianalisis dengan persamaan isoterm sorpsi (model Langmuir dan Freundlich) untuk mendapatkan parameter kesetimbangan sorpsi ion logam. Sedangkan kinetika sorpsi dianalisis dengan model pseudo-orde satu dan model pseudo-orde dua, yang merupakan model yang banyak direkomendasikan untuk sorpsi solute dari larutan (Ho dan McKay, 2000; Munawar, 2007). Untuk model pseudo-orde satu digunakan persamaan (1) yang merupakan integrasi persamaan Lagergren untuk kondisi batas $t=0$ hingga $t=t$ dan $q_{t}=0$ hingga $q_{t}=q_{t}$ :

$$
\log \left(q_{e}-q_{t}\right)=\log q_{e}-\frac{k}{2,303} t
$$

Sedangkan untuk model pseudo-orde dua digunakan persamaan (2), hasil integrasi persamaan Ho and McKay (1999) untuk kondisi batas $t=0$ hingga $t=t$ dan $q_{t}$ $=0$ hingga $q_{t}=q_{t}$ :

$$
\frac{t}{q_{t}}=\frac{1}{k q_{e}^{2}}+\frac{1}{q_{e}} t
$$

\section{Hasil Dan Pembahasan}

\subsection{Karakteristik material}

Gambut yang digunakan dalam penelitian ini diperkirakan merupakan gambut topogen, yaitu jenis gambut yang terbentuk dari vegetasi rawa yang membusuk dalam kondisi kekurangan oksigen dalam sistem topografi rawa yang depresif (Hariyanto, 2001; Darmawijaya, 1992). Hasil karakterisasi gambut ditunjukkan pada Tabel 2. 
Tabel 2. Karakteristik adsorben

\begin{tabular}{lc}
\hline \multicolumn{1}{c}{ Paramater, satuan } & Nilai \\
\hline Kadar air, \% & 51,49 \\
Bulk density, $\mathrm{kg} / \mathrm{m}^{3}$ & 0,35 \\
Karbon organik, \% & 16,13 \\
Nitrogen Total (NTK), & 1,09 \\
$\%$ & \\
Posfor, ppm & 2,94 \\
KTK, meq/100 g & 67,20 \\
Porositas, \% & 74,00 \\
pH & $4,01-4,70$ \\
\hline
\end{tabular}

Secara visual, gambut berwarna coklat hitam dengan bau yang khas dan kadar air tinggi. Mengacu pada hasil uji karakteristik material, gambut Cot Trieng memiliki sifat-sifat yang cukup mirip dengan gambut Ujung Pacu yang digunakan Dewi (2007) yang menggunakan Gambut Ujung Pacu. Hal ini cukup beralasan mengingat lokasi dan topografi kedua wilayah ini relatif dekat satu sama lain.

\subsection{Penyisihan COD}

Salah satu parmaeter kualitas air limbah yang sangat penting adalah parameter COD. Secara harfiah COD menggambarkan jumlah kebutuhan oksigen untuk mengoksidasi senyawa organik dalam air limbah. Makin tinggi nilai COD, maka makin tinggi kadar senyawa organik di dalam air limbah tersebut. Pada penelitian ini, COD menjadi parameter primer untuk mengevaluasi kinerja gambut lokal sebagai arsorben. Gambar 2 memperlihatkan nilai COD air limbah domestik pada berbagai variasi dosis dan perlakuan awal adsorben.

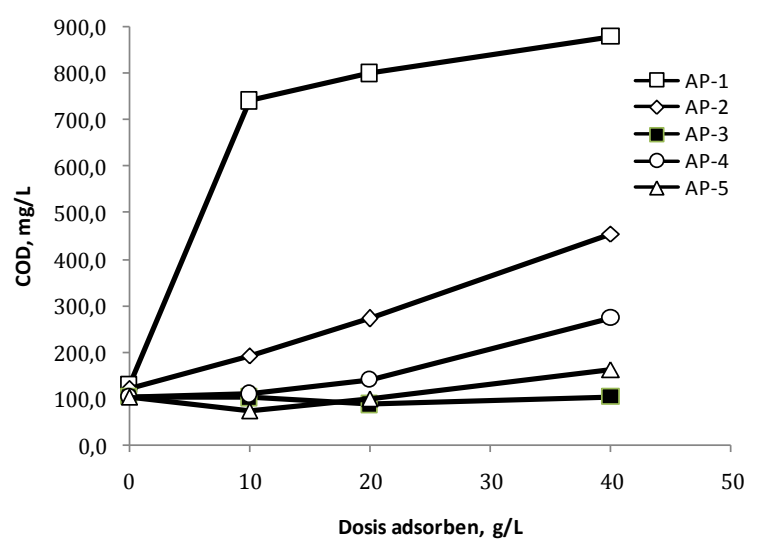

Gambar 2. COD air limbah pada berbagai variasi dosis dan perlakuan awal adsorben

Pada Gambar 2 terlihat bahwa perlakuan awal dan dosis adsorben berpengaruh besar terhadap nilai COD akhir air limbah domestik. Pada hampir semua perlkuan, COD 
air limbah meningkat, kecuali AP-3 dan AP-5, khususnya pada dosis 10 dan $20 \mathrm{~g} / \mathrm{L}$. Hal ini menunjukkan bahwa untuk adsorben selain AP-3 dan AP-5 fenomena pelepasan senyawa organik ke dalam air limbah yang kontak dengan gambut masih berlangsung. Ini adalah sifat khas material gambut yang menjadi kendala dalam setiap aplikasinya untuk tujuan penyisihan senyawa organik. Gambut adalah material diketahui yang kaya substansi organik, yang sebagiannya relatif mudah larut dalam air.

Jika mengacu kepada Gambar 2, pelepasan senyawa organik dapat dikatakan dapat diminimalisir pada gambut kering dengan perlakuan kapur dan besi (AP-3), serta gambut basah dengan perlakuan kapur dan besi (AP-3). Kondisi optimum dicapai oleh adsorben AP-1 pada dosis $10 \mathrm{~g}$ gambut per liter, di mana terjadi penyisihan COD sebesar 28,1\% (Gambar 3).

Fakta bahwa perlakuan awal dengan kapur dan besi berpengaruh terhadap penyisihan senyawa organik adalah sesuai dengan yang dilaporkan Buelna dan Belanger (1991) yang melakukan studi pengolahan air limbah kota dengan beberapa jenis gambut Kanada yang juga dipreparasi dengan kapur dan besi. Penyisihan optimum COD pada penelitian tersebut mencapai $72 \%$, sedangkan penyisihan optimum COD pada penelitian ini hanya $28,1 \%$. Perbedaan ini diperkirakan terjadi karena perbedaaan jenis gambut yang digunakan, perbedaaan metode preparasi gambut, serta perbedaan karakteristik air limbah.

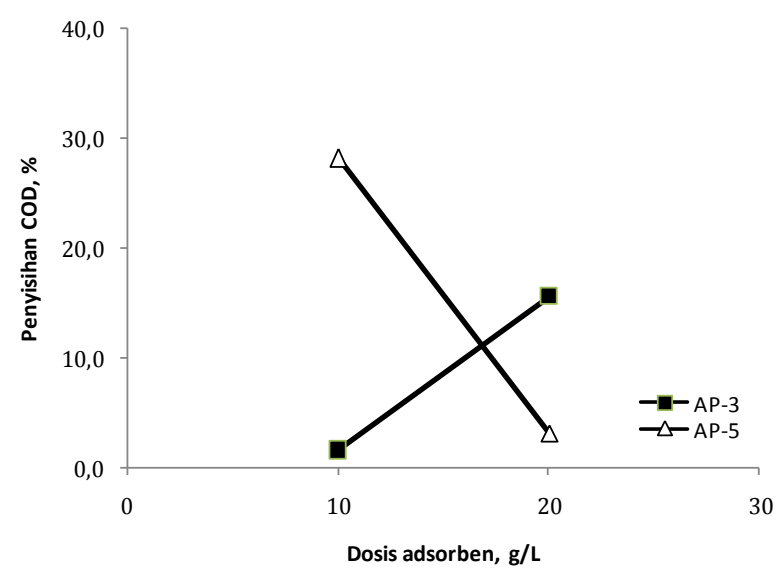

Gambar 3. Efisiensi penyisihan COD pada kondisi optimum

\subsection{Penyisihan deterjen}

Studi penyisihan deterjen dalam penelitian ini dilakukan hanya pada kondisi optimum proses sorpsi, yaitu menggunakan adsorben AP-3, AP-4, dan AP-5, mengingat parameter ini bukan merupakan parameter utama penelitian. Gambar 3 menampilkan konsentrasi deterjen pada berbagai variasi perlakuan dan dosis adsorben. Secara signifikan dari Gambar 4 terlihat bahwa konsentrasi residual deterjen dapat dikurangi hingga berada di bawah 2\% jika menggunakan adsorben AP-4 dan AP-5. 


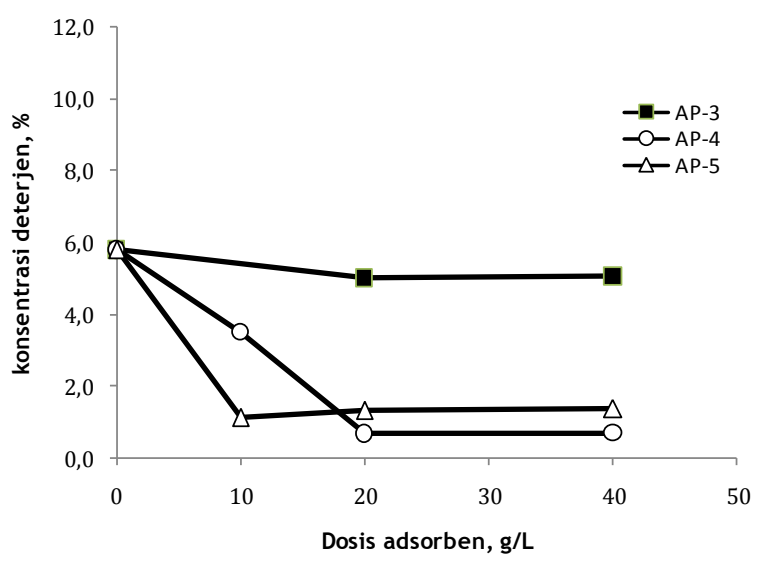

Gambar 4. Penyisihan deterjen pada kondisi optimum proses sorpsi

Efisiensi penyisihan deterjen pada adsorben AP-4 berada antara 39,5-88,6\%, dengan trend meningkat menurut kenaikan dosis adsorben. Pada adsorben AP-5, efisiensi penyisihan deterjen justru berkurang seiring naiknya dosis adsorben, dengan efisiensi antara 76,6-88,0\% (Gambar 5). Performansi penyisihan deterjen (ABS) yang diperoleh pada penelitian cukup konsisten dengan penelitian Tinh dkk (1971) yang melaporkan penyisihan ABS antara 72-92\% tergantung dari konsentrasi awal deterjen. Waktu kesetimbangan adsorpsi pada penelitian tersebut adalah 2 jam, masih di dalam range waktu 180 menit yang digunakan dalam penelitian ini.

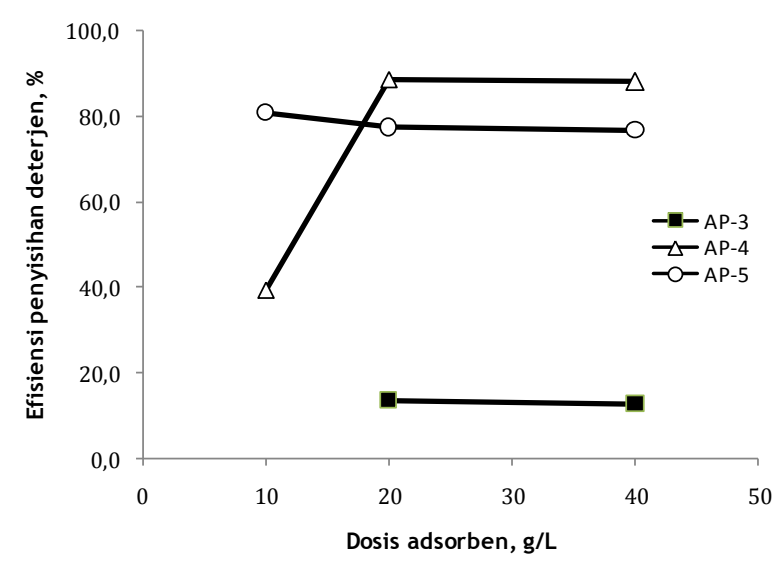

Gambar 5. Efisiensi penyisihan deterjen

\subsection{Penyisihan kekeruhan}

Perlakuan awal dan variasi dosis adasorben ternyata berpengaruh signifikan terhadap kekeruhan air limbah domestik. Makin banyak penggunaan kapur dalam perlakuan awal, ternyata makin tinggi turbidity residual air limbah. Di sisi lain, gambut segar dengan perlakuan kapur menunjukkan pengaruh paling baik dalam mereduksi 
kekeruhan. Turbidity residual air limbah untuk adsorben AP-5 adalah antara 1,2-4,4 NTU dengan trend makin menurun dengan naiknya dosis adsorben (Gambar 6).

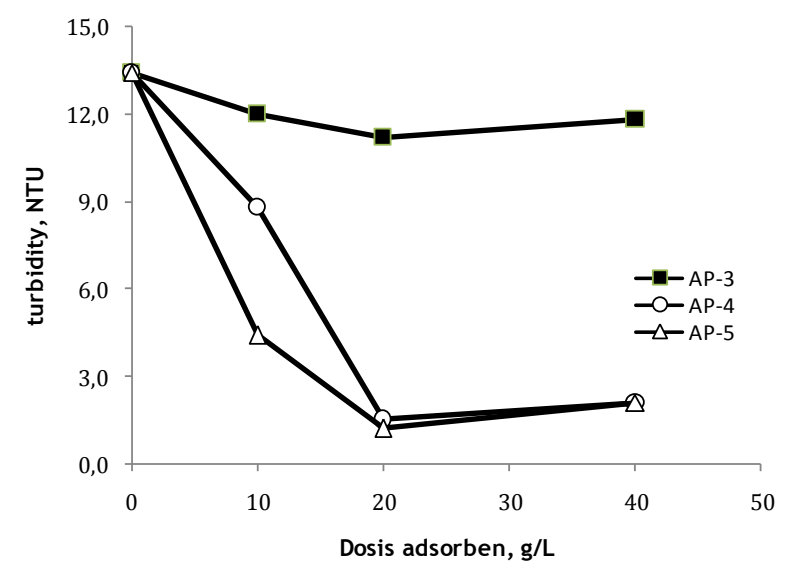

\section{Gambar 6. Penyisihan turbidity}

Efisiensi penyisihan kekeruhan mencapai $91 \%$ pada adsorben AP-5 dan 88,8\% pada adsorben AP-4 keduanya terjadi pada dosis $20 \mathrm{~g} / \mathrm{L}$ adsorben. Dosis tersebut merupakan dosis optimum adsorben untuk penyisihan kekeruhan. Pada dosis $40 \mathrm{~g} / \mathrm{L}$ efisiensi penyisihan kekeruhan berkurang antara $4,2-6,7 \%$ bila dibanding dosis optimum.

\subsection{Unjuk kerja bioadsorber}

Analisis unjuk kerja bioadsorber dilakukan pada kondisi optimum sistem batch, yaitu menggunakan adsorben AP-5, dengan rasio fas solid-liquid sebesar $10 \mathrm{~g} / \mathrm{L}$. Waktu operasi adalah 3 jam, dengan laju alir volumetrik air limbah domestik sebesar 10 L/menit. Tabel 3 menampilkan perbandingan karakteristik air limbah domestik sebelum dan sesudah proses sorpsi di dalam bioadsorber.

Tabel 3. Performansi bioadsorber

\begin{tabular}{|c|c|c|c|}
\hline \multirow{2}{*}{$\begin{array}{l}\text { Paramater, } \\
\text { Satuan }\end{array}$} & \multicolumn{2}{|c|}{ Nilai } & \multirow{2}{*}{$\begin{array}{c}\text { Efisiensi } \\
\text { Penyisihan, } \\
\%\end{array}$} \\
\hline & Awal & Akhir & \\
\hline $\mathrm{COD}, \mathrm{mg} / \mathrm{L}$ & 101,5 & 72,70 & $28,37 \%$ \\
\hline Deterjen, \% & 5,8 & 0,66 & $88,60 \%$ \\
\hline $\begin{array}{l}\text { Turbidity, } \\
\text { NTU }\end{array}$ & 21,9 & 1,20 & $91,00 \%$ \\
\hline $\begin{array}{l}\text { E. Coli, } 10^{-4} \\
\text { sel/100 mL }\end{array}$ & 182,0 & 0,99 & $94,79 \%$ \\
\hline
\end{tabular}

Berdasarkan data yang diperoleh (Tabel 3), bioadsorber berbasis gambut lokal dengan perlakuan kapur dan besi ternyata mampu mereduksi beberapa parameter utama air limbah seperti COD, deterjen, kekeruhan dan bakteri E. Coli dengan efisiensi penyisihan antara 28,37 - 94,79\%. Dibandingkan dengan studi terdahulu yang 
dilakukan oleh Buelna dan Belanger (1991), biadsorber yang dikembangkan menunjukkan kinerja yang cukup kompetitif. Kelemahan sistem ini adalah penyisihan senyawa organik (COD) yang tergolong rendah (28,37\%). Namun di sisi lain, sistem ini mampu mereduksi deterjen, kekeruhan dan bakteri $E$. Coli dengan efsiensi cukup tinggi $(88,6-94,79 \%)$.

Unjuk kerja bioadsorber untuk penyisihan COD pada sistem batch dianalisis dengan model kinetika mekanistik berbasis kapasistas fasa solid, yaitu model pseudo orde satu (Ho dan McKay, 1998) dan pseudo orde dua (model Lagergren). Dinamika konsentrasi residual COD di dalam air limbah selama proses sorpsi di dalam bioadsorber ditunjukkan pada Gambar 7. Dari gambar dapat diamati bahwa sorpsi bahan organik berlangsung relatif lambat, dengan efisiensi penyisihan yang relatif rendah. Efisiensi penyisihan COD pada akhir proses sorpsi adalah 28,37\%. Data ini cukup konsisten dengan hasil percobaan optimasi sistem batch.
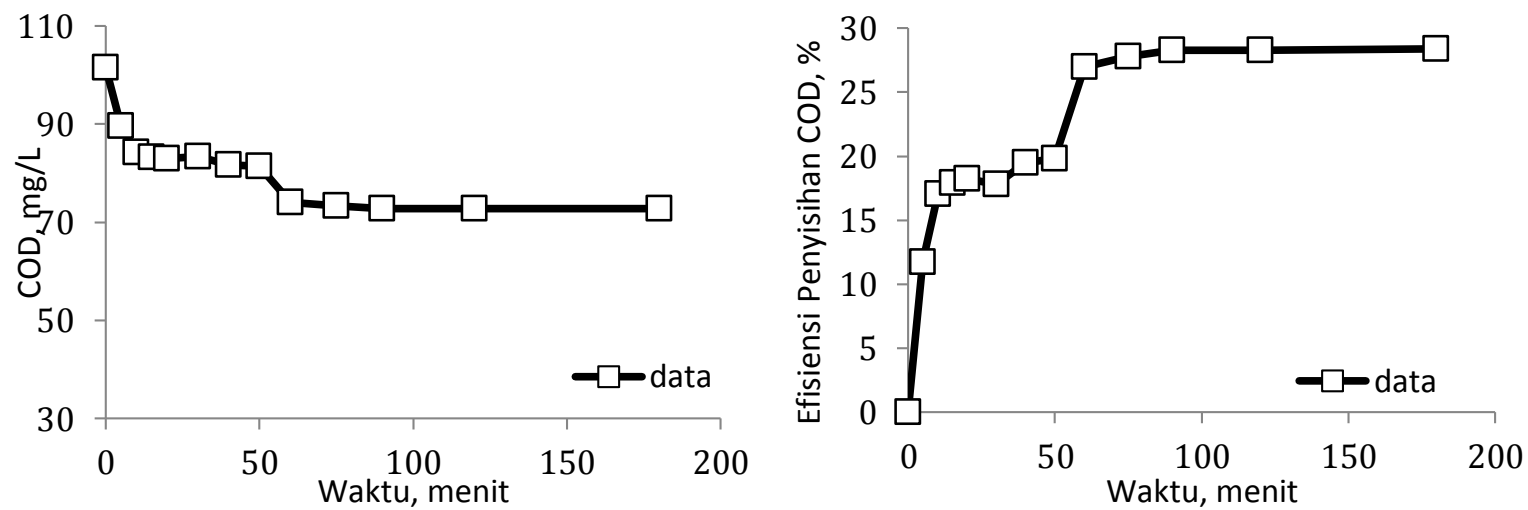

Gambar 7. Dinamika konsentrasi residual dan penyisihan COD terhadap waktu

Koefisien kinetika adsorpsi bahan organik dianalisis dengan model kinetika pseudo- orde 1 (model Lagergren) dan model kinetika pseudo-orde 2 (model Ho \& McKay), menggunakan persamaan (1) dan (2). Model yang cocok ditentukan berdasarkan nilai koefisien determinasi $\left(\mathrm{R}^{2}\right)$ kedua model tersebut. Gambar 8 menampilkan analisis regresi model pseudo orde 1 dan orde 2.
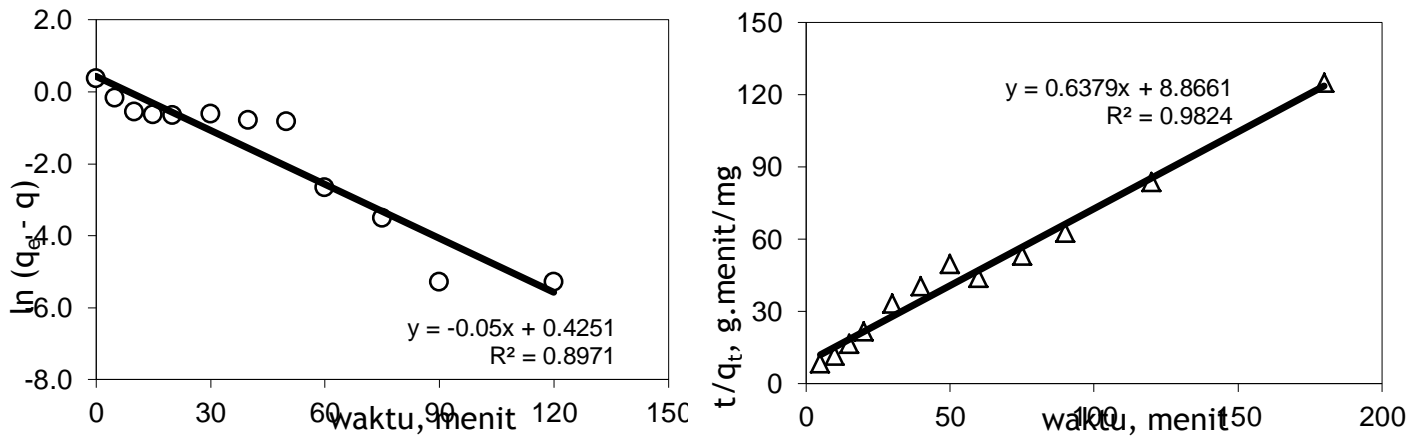

Gambar 8 Analisis regresi model kinetika sorpsi 
Hasil analisis model kinetika sorpsi menunjukkan bahwa model kinetika pseudoorde 2 memiliki koefisien determinasi lebih tinggi $(0,98)$ dibandingkan model pseudoorde $1(0,89)$. Data ini menunjukkan bahwa model pseudo-orde lebih cocok untuk representasi kinetika sorpsi senyawa organik pada partikel gambut. Nilai konstanta kinetika sorpsi $(k)$ dan kapasitas sorpsi pada kesetimbangan $\left(q_{\mathrm{e}}\right)$ untuk sistem ini masing-masing adalah 0,046 g.menit/mg dan 1,568 mg/g (Tabel 4).

Tabel 5.4 Parameter kinetika sorpsi

\begin{tabular}{lccc}
\hline \multicolumn{1}{c}{$\begin{array}{c}\text { Model } \\
\text { kinetika }\end{array}$} & $R^{2}$ & $\begin{array}{c}q_{\mathrm{e}}, \\
\mathrm{mg} / \mathrm{g}\end{array}$ & $K$ \\
\hline $\begin{array}{l}\text { Pseudo-orde } \\
1\end{array}$ & 0,897 & 1,572 & 0,050 \\
$\begin{array}{l}\text { Pseudo-orde } \\
2\end{array}$ & 0,982 & 1,568 & 0,046 \\
\hline
\end{tabular}

\section{Kesimpulan}

Gambut lokal Indonesia memiliki potensi cukup baik untuk digunakan sebagai adsorben untuk pengolahan air limbah domestik. Preparasi awal dengan kapur dan besi terbukti efektif untuk meningkatkan kinerja gambut lokal sebagai adsorben. Studi yang telah dilakukan menunjukkan bahwa gambut segar dengan perlakuan kapur dan besi mampu mereduksi beberapa parameter utama air limbah domestik dengan efisiensi optimum $28,1 \%$ untuk penyisihan COD, $88,6 \%$ untuk penyisihan deterjen, dan $91 \%$ untuk penyisihan kekeruhan.

\section{Daftar Pustaka}

Andriesse, J.P. (1997), The Reclamation of Peatswamps and Peat in Indonesia, CWS Monograph, No. 1, Widiatmaka, Editor, Center for Wetland Studies, IPB, Bogor

APHA (1998), Standard Methods for Examination of Water and Waste Water, 4th edition, American Public Health Association, Washington DC.

Coupal, B, Lalancette, J.M. (1976), The treatment of wastewater with peat moss, Water Research, 10, 1071-1076.

Crist R.H, Martin, J.R, Chonko, J, dan Crist D.R. (1996), Uptake of metals on peat moss: an ion exchange process, Environmental Science and Technology, 30, 2456-2461.

Darmawijaya, M.I. (1992), Klasifikasi Tanah: Dasar Teori Bagi Peneliti Tanah dan Pelaksana Pertanian di Indonesia, Cetakan ke-2, Gadjah Mada University Press, Yogyakarta, 277-286.

Dewi, R, Sari, R, Hakim, L. (2007), Pemanfaatan Tanah Gambut sebagai Adsorben Senyawa Ammonia dalam Limbah Cair Industri Tahu, Jurnal Reaksi, 5(10), Desember 2007, 24-27.

Hariyanto, S. (2001), Alternatif pemanfaatan gambut dalam penanganan limbah cair, Jurnal Kimia Lingkungan, 3(1), 53-59.

Ho, Y.S, John Wase, D.A, Forster, C.F. (1995), Batch nickel removal from aqueous solution by sphagnum moss peat, Water Research, 29(5), 1327-1332.

Montgomery, J.M. (1985), Water Treatment Principles and Design, John Wiley \& Sons Inc., New York, 174-194.

Notodarmojo, S. (2005), Pencemaran Tanah dan Air Tanah, Penerbit ITB, Bandung, 230-272. 


\section{$232 \mid$ Munawar}

Raji, C., Anirudhan, T.S. (1998), Batch Cr(VI) removal by polyacrylamide-grafted sawdust, Water Research, 32(12), 3772-3780.

Sabiham, S., Prasetyo, T.B., Dohong, S. (1997), Phenolic Acids in Indonesian Peat, Biodiversity and Sustainability of Tropical Peatlands, Riley, J.O., Page, S.E, Editor, Samara Publishing Ltd., UK, 289-292.

Sakadevan, K., Bavor, H.J. (1998), Phospate adsorption characteristics of soils, slags and zeolite to be used as substrate in constructed wetland systems, Water Research, 32(2), 393-399.

Sugandhy, A. (1997), Conservation and sustainable use of tropical peatland in Indonesia, whitin the national strategy for environmental management of wetland ecosystems, Biodiversity and Sustainability of Tropical Peatlands, Riley, J.O., Page, S.E, Editor, Samara Publishing Ltd., UK, 23-33.

Tan, K.H. (1998), Dasar-Dasar Kimia Tanah, Cetakan ke-5, Goenadi, D.H., Radjagukguk, B., Penerjemah, Gadjah Mada University Press, Yogyakarta, 183-184.

Tchobanoglous, G, Burton, F.L, dan Stensel H.D. (2003), Wastewater Engineering: Treatment and Reuse, 4th Edition, Metcalf \& Eddy, Inc., McGraw-Hill Inc., NY.

Weber, Jr., W.J. (1972), Physicochemical Processes for Water Quality Control, John Wiley \& Sons Inc. New York, 199-255.

Weber, Jr., W.J., DiGiano, F.A. (1996), Process Dynamics in Environmental Engineering, John Wiley \& Sons Inc. New York, 345-390. 